\title{
Taxonomic revision of the Afrotropical scarab beetle genus Cerhomalus Quedenfeldt, 1884 (Coleoptera: Scarabaeidae: Orphninae)
}

\author{
Andrey V. FROLOV ${ }^{1, *} \&$ Lilia A. AKHMETOVA ${ }^{2}$ \\ ${ }^{1,2}$ Laboratory of Insect Systematics, Zoological Institute, Russian Academy of Sciences, \\ Universitetskaya nab., 1, St.-Petersburg, 199034 Russia. \\ *Corresponding author: frolov@scarabaeoidea.com \\ ${ }^{2}$ Email: akhmetova@scarabaeoidea.com \\ ${ }^{1}$ urn:1sid:zoobank.org:author:FB31931B-44B9-4C22-963B-1023CEA88A21 \\ ${ }^{2}$ urn:1sid:zoobank.org:author:BA35DDDD-6E6A-47A4-AB73-965EB4A92CC3 \\ $1 \odot$ https://orcid.org/0000-0002-6724-6828 \\ $2 \odot$ https://orcid.org/0000-0002-2151-1278
}

\begin{abstract}
The Afrotropical scarab beetle genus Cerhomalus Quedenfeldt, 1884 (Coleoptera: Scarabaeidae) is revised. Two new species are described: $C$. quedenfeldti sp. nov. and C. petrovitzi sp. nov. A new combination, Cerhomalus absconditus (Petrovitz, 1971) comb. nov., is established. The genus occurs in Central and West Africa with the majority of records from the Congo Basin. Keys, descriptions, illustrations of habitus and male genitalia, and distributional record map are given.
\end{abstract}

Keywords. Orphnines, Congo Basin, Angola, Republic of the Congo, Democratic Republic of the Congo.

Frolov A.V. \& Akhmetova L.A. 2021. Taxonomic revision of the Afrotropical scarab beetle genus Cerhomalus Quedenfeldt, 1884 (Coleoptera: Scarabaeidae: Orphninae). European Journal of Taxonomy 739: 36-50.

https://doi.org/10.5852/ejt.2021.739.1265

\section{Introduction}

The scarab beetles of the subfamily Orphninae Erichson, 1847, are a predominantly tropical group of insects distributed mostly in the southern continents. The Afrotropical Region is the centre of the diversity of orphnines, with over a hundred species occurring from Sahel in the north to Little Karoo in the south (Paulian 1948; Petrovitz 1971; Frolov 2005, 2013; Frolov \& Akhmetova 2016, 2020). Among the Afrotropical orphnines, there is a small group, Cerhomalus Quedenfeldt, 1884, which included two nominal species and was treated by different authors as either a distinct genus or a subgenus of Orphnus Macleay, 1819.

Cerhomalus was erected by Quedenfeldt (1884) as a genus within the Orphninae (Orphnidae sensu Quedenfeldt) for a single species, C. mechowi Quedenfeldt, 1884, described in the same paper. In the diagnosis of the genus, Quedenfeldt (1884) mentioned the large size of the beetles (twice as large as 
specimens of Orphnus) and the clypeus with a transverse keel. After the original description, Cerhomalus was mentioned in a few papers including the catalogues by Arrow (1912) and Schmidt (1913). Paulian (1948) noted that the genus was more evolved than Orphnus but retained some ancestral characters; he did not discuss it in any detail, though. Petrovitz's (1971) work on the genus Orphnus was the only publication that included additional original information about Cerhomalus. He lowered the rank of Cerhomalus to a subgenus of Orphnus and described the second species of the genus, O. (C.) absconditus (Petrovitz 1971).

Cerhomalus has not attracted attention since Petrovitz (1971). In the course of our studies of the Afrotropical Orphninae, we have re-examined the material on Cerhomalus accumulated in all available collections to date and found that four distinct species of this group can be recognized. This necessitated examination of the types of the nominal species and a taxonomic revision of Cerhomalus. The aims of the present paper are to describe two species as new for science, provide a diagnostic key to all Cerhomalus species and illustrate their characters, as well as re-evaluate its subgeneric status suggested by Petrovitz (1971).

\section{Material and methods}

Morphological terminology follows Frolov et al. (2016). Preparation of specimens, digital images and locality map follow Frolov et al. (2017). Labels of the type specimens are cited verbatim with separate labels separated by a slash '/.

The material used in this work is deposited in the following organisations (curators in parentheses):

$\mathrm{BMNH}=$ Natural History Museum, London, UK (Maxwell Barclay)

HNHM = Hungarian Natural History Museum (Termászettudományi Múzeum), Budapest, Hungary (Otto Merkl)

MCSNG = Natural History Museum Giacomo Doria, Genova (Roberto Poggi)

MHNG = Natural History Museum, Geneva, Switzerland (Giulio Cuccodoro)

MNHN = National Museum of Natural History, Paris, France (Olivier Montreuil)

RMCA = Royal Museum for Central Africa, Tervuren, Belgium (Didier Van den Spiegel, Stéphane Hanot)

SDCMR = Sergey Dementev private collection, Moscow (Sergey Dementev)

ZMHUB = Museum of Natural History, Leibniz Institute for Evolution and Biodiversity Science, Berlin, Germany (Johannes Frisch, Joachim Willers)

\section{Results}

\section{Taxonomic treatments}

Class Insecta Linnaeus, 1758

Order Coleoptera Linnaeus, 1758

Family Scarabaeidae Latreille, 1802

Subfamily Orphninae Erichson, 1847

Cerhomalus Quedenfeldt, 1884

Figs 1-6

Cerhomalus Quedenfeldt, 1884: 289, pl. VIII, fig. 7.

Cerhomalus - Karsch 1887: 5. — Quedenfeldt 1888: 165. — Arrow 1912: 30. — Schmidt 1913: 71. — Paulian, 1948: 11. 
Orphnus (Cerhomalus) Quedenfeldt - Petrovitz 1971: 2.

\section{Type species}

Cerhomalus mechowi Quedenfeldt, 1884, by monotypy.

\section{Diagnosis}

The largest orphnines (body length 15-22 mm). Colour uniformly dark brown to black. Clypeus of both sexes with a transverse keel, higher and apically bilobate in males (Fig. 1A) and lower but distinct in females (Fig. 1G). Pronotal disc of males more or less depressed, sometimes slightly excavated, but distinct pronotal lateral processes always absent. Elytra convex, without ridges, with humeral umbones. Elytral surface sparsely covered with rounded punctures; punctures arranged in longitudinal striae, which are more distinct on disc. Protibiae with 3 strong outer teeth similar in both sexes. Apical protibial spur absent in males. Middle and posterior legs similar in shape; posterior femora and tibiae about $1 / 8$ longer than middle ones. Parameres symmetrical, not setose apically, very wide in lateral view; inner sides of parameres with longitudinal excavations in 3 species (Fig. 1E). Ventroapical part of phallobase strongly sclerotized, in shape of 2 incompletely separated sclerites (Figs 1C, 5A, va. phlb. sc.).

\section{Species composition}

The genus comprises four species including two new ones described below.

\section{Distribution}

The genus occurs in Central and West Africa with the majority of records from the Congo Basin (Fig. 6).

\section{Key to species of Cerhomalus (males)}

1. Apices of parameres rounded in apical view, without semi-circular excavations (Fig. 2G, J) and without keels or fossae on ventral side (Fig. 2K); base of elytra with somewhat tile-shaped punctures (Fig. 2A-B) Cerhomalus absconditus (Petrovitz, 1971) comb. nov.

- Apices of parameres with semi-circular excavations in apical view (Figs 1E, 3F, 4F, J) and with more or less developed fossae on ventral sides bordered with keel (Fig. 1F); base of elytra smooth (Figs 1A, G, I, 3A, C, 4A, C)

2. Ventral fossae on apices of parameres not bordered proximally (Fig. 4G, K, arrowed); apices of parameres in lateral view acute-angled (Fig. 4D, H) Cerhomalus quedenfeldti sp. nov.

- Ventral fossae on apices of parameres completely bordered (Figs 1F, 3G); apices of parameres in lateral view right-angled (Figs 1C, 3D)

3. Widened part of paramere (in lateral view) about half length of paramere (Fig. 1C); ventral fossa of paramere shorter and wider (Fig. 1F) Cerhomalus mechowi Quedenfeldt, 1884

- Widened part of paramere (in lateral view) about two thirds length of paramere (Fig. 3D); ventral fossa of paramere longer and narrower (Fig. 3G) Cerhomalus petrovitzi sp. nov.

Cerhomalus mechowi Quedenfeldt, 1884

Figs 1, 5B, 6

Cerhomalus mechowi Quedenfeldt, 1884: 290.

Cerhomalus mechowi-Arrow 1912: 30. — Schmidt 1913: 71.

Orphnus mechowi (Quedenfeldt) - Petrovitz 1971: 2. 


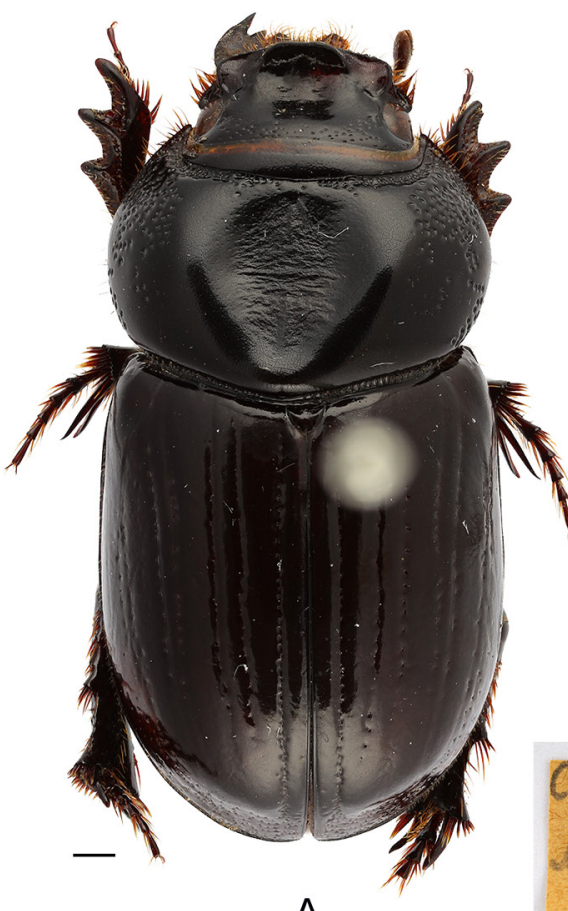

A

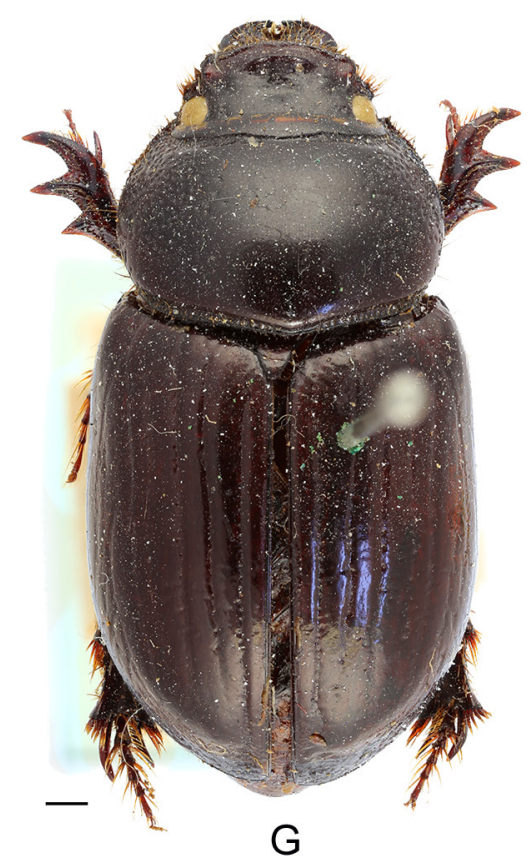

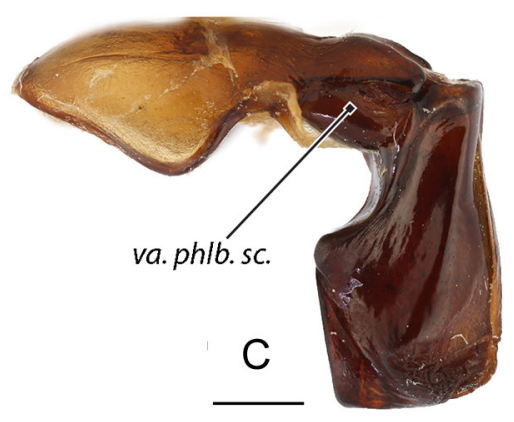
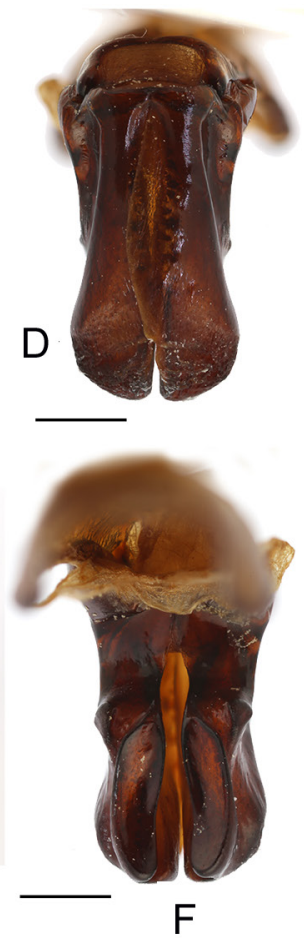

E

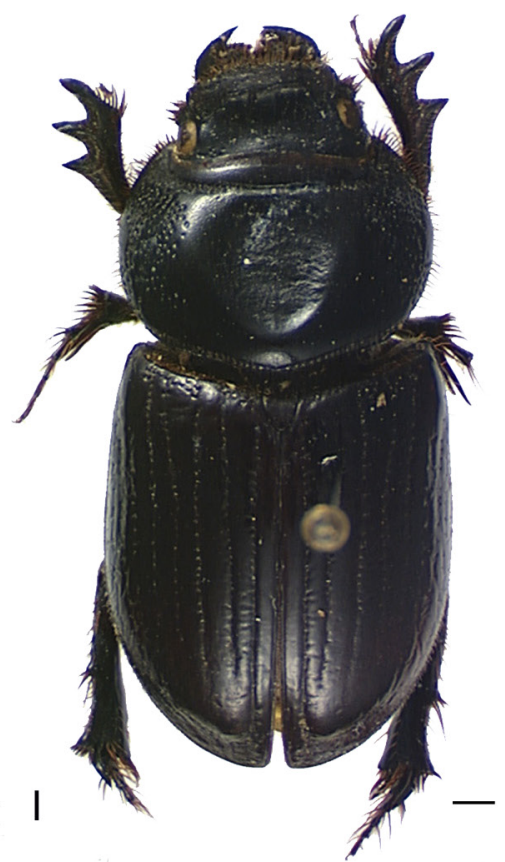

Fig. 1. Cerhomalus mechowi Quedenfeldt, 1884. A-F. Lectotype, §ิ (MNHN). G. Paralectotype, $q$ (MNHN). H-I. Paralectotype, ô (ZMHUB). A, G, I. Habitus in dorsal view. B, H. Labels. C. Aedeagus in lateral view. D. Parameres in dorsal view. E. Parameres in apical view. F. Parameres in ventral view. Abbreviation: va. phlb. $s c .=$ ventroapical phallobase sclerite. Scale bars $=1.0 \mathrm{~mm}$. 


\section{Differential diagnosis}

Cerhomalus mechowi is most similar to C. petrovitzi sp. nov. but differs from it in having the widened part of a paramere (in lateral view) about half the length of the paramere (Fig. 1C, vs about $2 / 3$ the length of the paramere in C. petrovitzi sp. nov. (Fig. 3D)) and the ventral fossa of a paramere shorter and wider (Fig. 1F, vs longer and narrower in C. petrovitzi sp. nov. (Fig. 3G)).

\section{Type material}

Lectotype (here designated)

ANGOLA - ô; "Quango Strom [Quango River] Major v. Mechow / Ex-Musaeo Quedenfeldt / Cerhomalus mochowi [sic!] Qd / TYPE / Museum Paris ex Coll. R. Oberthur"; MNHN.

\section{Paralectotype}

ANGOLA • 1 क; same collection data as for lectotype; MNHN • 1 đ̊; "Malange v. Mechow"; ZMHUB.

\section{Remarks}

The male paralectotype housed in ZMHUB lacks the aedeagus.

\section{Distribution}

The species is known from two localities in northwestern Angola (Fig. 6).

Cerhomalus absconditus (Petrovitz, 1971) comb. nov.

Figs 2, 5A, 6

Orphnus (Cerhomalus) absconditus Petrovitz, 1971: 3.

\section{Differential diagnosis}

Cerhomalus absconditus can be easily separated from congeners by having the apices of the parameres rounded (in apical view), without semi-circular excavations (Fig. 2G, J) and without keels or fossae on ventral side (Fig. 2K), and the base of elytra with somewhat tile-shaped punctures (Fig. 2A-B).

\section{Material examined}

\section{Holotype}

DEMOCRATIC REPUBLIC OF THE CONGO • đ̄; "COLL. MUS. CONGO Tshuapa: Yokamba /1953 J. Stevenard / HOLOTYPUS / O. (Cerhomalus) absconditus n.sp. Petrovitz"; RMCA.

\section{Paratypes}

DEMOCRATIC REPUBLIC OF THE CONGO • 1 q "COLL. MUS. CONGO Kasai: Ipamu -1937 R. Soeur Imelda / PARATYPUS / O. (Cerhomalus) absconditus n.sp. Petrovitz”; RMCA • 5 qo+; "COLL. MUS. CONGO Kwango: Djuma 1953 /R.P.G. Leta/ PARATYPUS / O. (Cerhomalus) absconditus n.sp. Petrovitz / coll. Petrovitz"; RMCA • 1 đ ; "COLL. MUS. CONGO Lulua: Kapanga XI-1933 F.G. Overlaet / PARATYPUS / O. (Cerhomalus) absconditus n.sp. Petrovitz"; RMCA • 1 ð’; "MUS. ROY. AFR. CENTR. Kasai: terr. Dekese I.1960 F. Francois / PARATYPUS / O. (Cerhomalus) absconditus n.sp. Petrovitz"; RMCA • 1 क; "MUSEE DU CONGO Kasai: Don de la Cie du Kasai / PARATYPUS / R. DET. 1939 F / O. (Cerhomalus) absconditus n.sp. Petrovitz”; RMCA • 1 đ̊; "MUSEE DU CONGO Kasai: Ipamu -VIII -1922 P. Vanderijst / PARATYPUS / R. DET. 1939 F / O. (Cerhomalus)

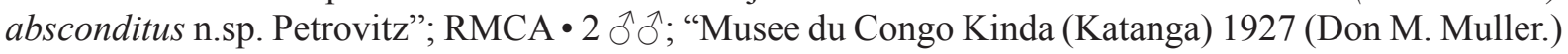
/ Kinda Katanga 1926 Congo / O. (Cerhomalus) absconditus n.sp. Petrovitz / PARATYPUS / R. DET. 1939 F / 139"; MHNG • 1 P; "MUSEE DU CONGO Murlambongo (Idiofa) - 1930 (Les Soeurs de la 

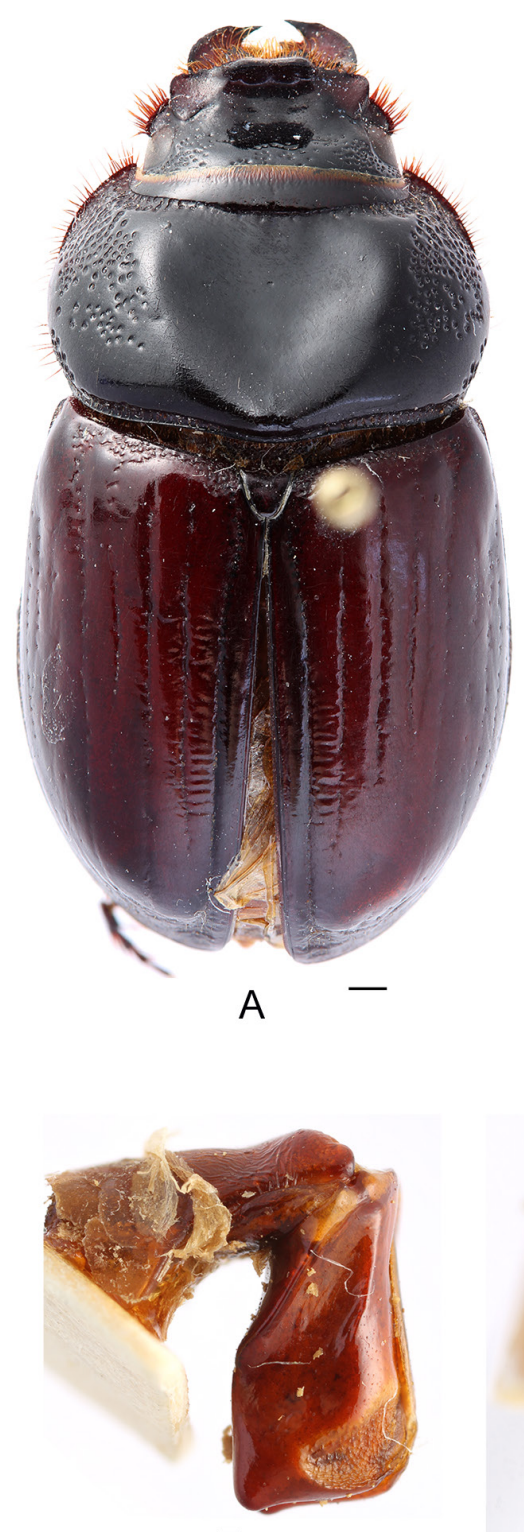

$\mathrm{E}$

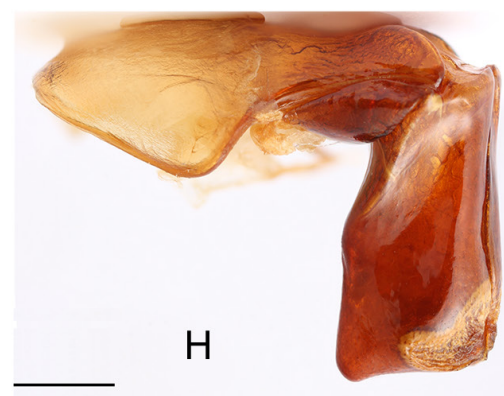

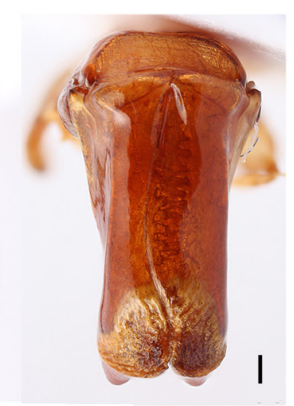
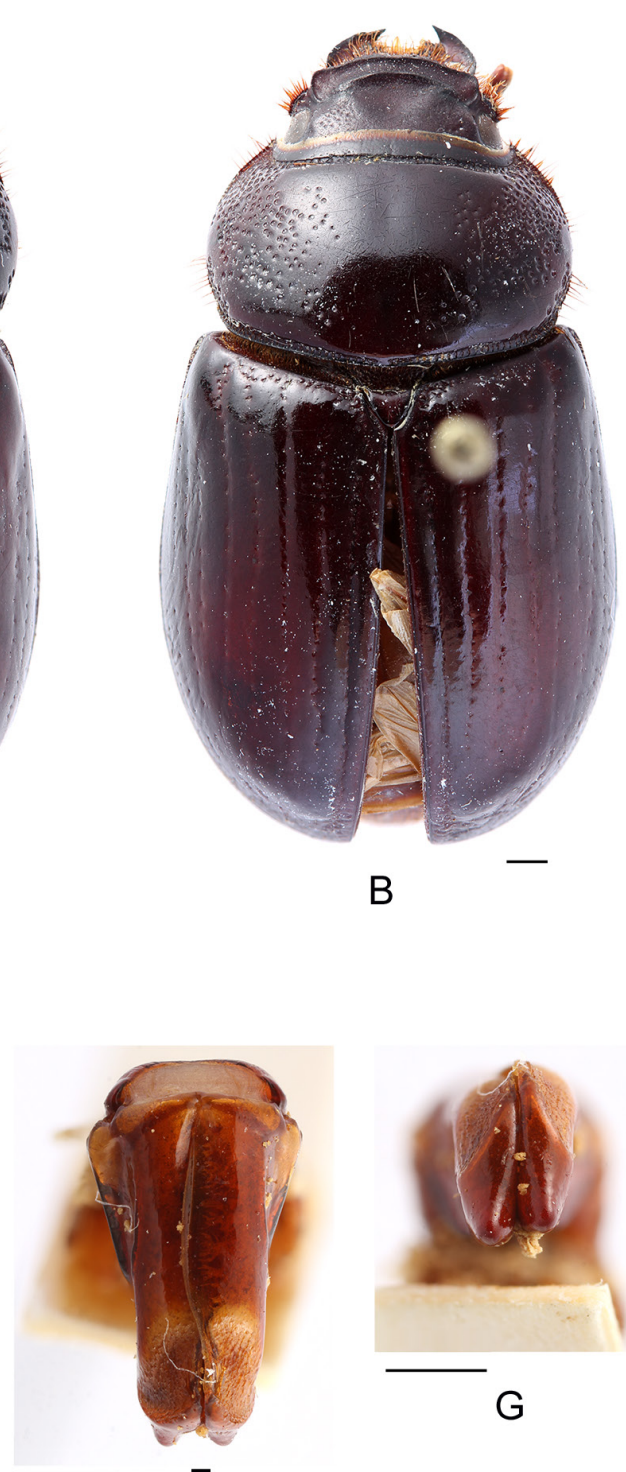

$\mathrm{F}$
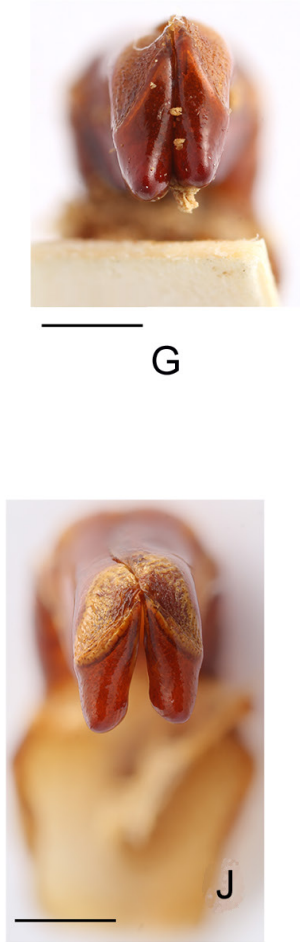

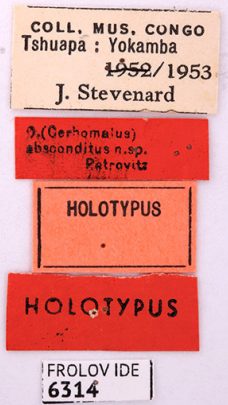

C

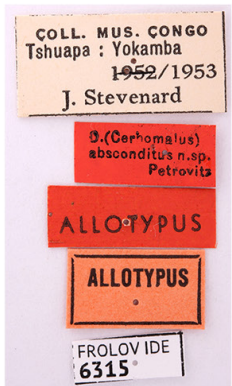

D

Fig. 2. Cerhomalus absconditus (Petrovitz, 1971). A, C, E-G. Holotype, ô (RMCA). B, D. Paratype, 우 (RMCA). H-K. Male specimen from Andrada, Angola. A-B. Habitus in dorsal view. C, D. Labels. E, H. Aedeagus in lateral view. F, I. Parameres in dorsal view. G, J. Parameres in apical view. K. Parameres in ventral view. Scale bars $=1.0 \mathrm{~mm}$. 
Mission) / PARATYPUS / O. (Cerhomalus) absconditus n.sp. Petrovitz"; RMCA • 1 ô; "Musee du Congo Sankuru: Komi (Lodja) 27-I-1930 J. Ghesquiere / R. DET 1939 F / Cerhomalus mechowi Qued. / O. (Cerhomalus) absconditus n.sp. Petrovitz / PARATYPUS"; RMCA • 1 万̃; "COLL. MUS. CONGO Sankuru: Katako-Kombe VIII - 1952 Dr M. Fontaine / O. (Cerhomalus) absconditus n.sp. Petrovitz / PARATYPUS / PARATYPUS"; MCSNG • 1 ô, 1 क; "COLL. MUS. CONGO Tshuapa : Ikela 1956 R. Deguide / PARATYPUS / O. (Cerhomalus) absconditus n. sp. Petrovitz"; RMCA • 1 q; "COLL. MUS. CONGO Tshuapa : Ikela 1956 R.P. Lootens / PARATYPUS / O. (Cerhomalus) absconditus n. sp. Petrovitz"; RMCA - 1 क; "COLL. MUS. CONGO Tshuapa: Bosekele VI-1952 J. Van Vynckt / O. (Cerhomalus) absconditus n.sp. Petrovitz / PARATYPUS"; RMCA • 1 क; "COLL. MUS. CONGO Tshuapa: Yokamba /1953 J. Stevenard / ALLOTYPUS / O. (Cerhomalus) absconditus n.sp. Petrovitz"; RMCA - 1 ơ; "COLL. MUS. CONGO Terr. de Dibaya Kamponde 1945 Rev. Fr. ALLAER 1945 / PARATYPUS / O. (Cerhomalus) absconditus n. sp. Petrovitz"; RMCA • 1 +; "COLL. MUS. CONGO Katoka-Luluabourg / -1938 R. P. VANKERCKHOVEN / PARATYPUS / O. (Cerhomalus) absconditus n.sp. Petrovitz / coll. Petrovitz"; RMCA • 1 đ̃; "MUSEE DU CONGO Luebo -III-1931. 1 ex. J.P. Colin / O. (Cerhomalus) absconditus n.sp. Petrovitz / PARATYPUS"; RMCA.

\section{Other material}

DEMOCRATIC REPUBLIC OF THE CONGO • 1 \%; Équateur, Tshuapa, Etata; Aug.-Sep. 1969; J. Hauwaert leg.; RMCA.

ANGOLA • 1 đ, 3 우; Bié, Catabola; 15-27 Sep. 2012; T. Lackner leg.; BMNH • 4 q $q$; Lunda Norte, Andrada; $7^{\circ} 41^{\prime}$ S, $21^{\circ} 17^{\prime}$ E; Aug.-Sep. 1952; M. Fetchkowsky leg.; RMCA • 2 q 9 ; Dundo; Sep. 1948; Machado leg.; RMCA $\bullet 1$ ऊ ; Cuando Cubango Province, $\mathrm{N}$ of Menongue City; 1600 m a.s.1.; 22 Nov. 2019; S. Dementev leg.; SDCMR.

CAMEROON • 1 ठ̊; 1912; BMNH.

\section{Distribution}

This is the most widely distributed species of the genus. The majority of records are from the Congo basin, but the species occurs up to Cameroon in the north (no precise locality is recorded) and to the Ancient Plateau in Angola in the south (Fig. 6).

Cerhomalus petrovitzi sp. nov.

urn:1sid:zoobank.org:act:A04DF237-5C78-4B76-BEDB-7453CCEAB827

Figs $3,5 \mathrm{C}, 6$

\section{Differential diagnosis}

Cerhomalus petrovitzi sp. nov. is most similar to C. mechowi in having the ventral fossae on the apices of the parameres completely bordered (Figs 1F, 3G) and the apices right angled in lateral view (Figs 1C, 3D) but can be separated from it in having the widened part of a paramere (in lateral view) about two thirds the length of the paramere (Fig. 3D) and ventral fossa of a paramere longer and narrower (Fig. 3G).

\section{Etymology}

The new species is named after Rudolf Petrovitz (1906-1974), a German coleopterist.

\section{Type material}

Holotype

DEMOCRATIC REPUBLIC OF THE CONGO • $\widehat{\jmath}$; "MUSEE DU CONGO BELGE KISANTU P. Goossens"; MNHN. 


\section{Paratypes}

DEMOCRATIC REPUBLIC OF THE CONGO • $2 \lambda \hat{\jmath}, 1$; same collection data as for holotype; RMCA • 1 ô; "MUSEE DU CONGO Belge [Kasaï-Occidental] (Don M. Corpentier)"; MHNG.

\section{Other material}

NIGERIA• 1 O̊; "Nigeria W. Afr. / (Staudinger coll.) 1914-412.”; BMNH.

\section{Description}

Male, holotype (Fig. 3A-B, D-G)

Body length $20.1 \mathrm{~mm}$. Colour uniformly brown to black.

Anterior margin of frontoclypeus somewhat rectangular, slightly convex in middle, bordered and slightly serrate in dorsal view (Fig. 3A). Frontoclypeus with a keel-shaped transverse process near anterior margin; height of keel about half its width. Surface of frontoclypeus almost smooth, with minute punctures. Eye tubercles feebly developed. Eyes rather large: width about $1 / 6$ distance between eyes in dorsal view. Antennae 10-segmented.

Pronotum widely rounded laterally, as wide as elytra. Anterior border wide. Basal border narrow, keelshaped, separated from pronotal disc by deep groove with row of longitudinally elongated punctures. Pronotal disc with a rounded depression occupying more than half of the surface, somewhat rugose anteriorly. Most of pronotum surface covered with minute punctures separated by more than 3 puncture diameters. Anterolateral angles with much larger and denser punctures; posteriolateral angles with same punctures but in smaller numbers.

Scutellum subtriangular, narrowly rounded apically, about $1 / 10$ length of elytra.

Elytra 1.1 times longer than wide, with distinct humeral humps. Elytra widest in middle, lateral margins almost parallel in basal half. First (sutural) stria distinct, as groove with row of punctures. Other stria before humeral humps as rows of round setiferous punctures. Striae laterad of stria 5 feebly distinct. Elytral intervals covered with minute punctures, somewhat sparser than those on pronotum.

\section{Macropterous.}

Abdominal sternite 8 medially longer than sternites 6 and 7 combined; sternite 6 about as long as sternite 7. Pygidium invisible from above, with slightly truncate apex. Plectrum triangular with rounded apex, wider than long.

Aedeagus. Ventral fossae on the apices of the parameres completely bordered, long and narrow (Fig. 3G); apices of parameres right angled in lateral view, its widened part (in lateral view) about two thirds the length of paramere (Fig. 3D).

\section{Female}

Female (Fig. 3C) differs from male in having a relatively smaller, convex pronotum without tubercles and only with a small depression medially, frontoclypeus with much smaller, low keel not bimodal apically, protibial spur, and pygidium with rounded apex. Body length $21.0 \mathrm{~mm}$.

\section{Variation}

Body length of examined male paratypes varies from 17.0 to $22.5 \mathrm{~mm}$.

\section{Distribution}

The species is known from western Democratic Republic of the Congo (Fig. 6). The record from Nigeria is doubtful and need confirmation, therefore the specimen is not included in the type series. 

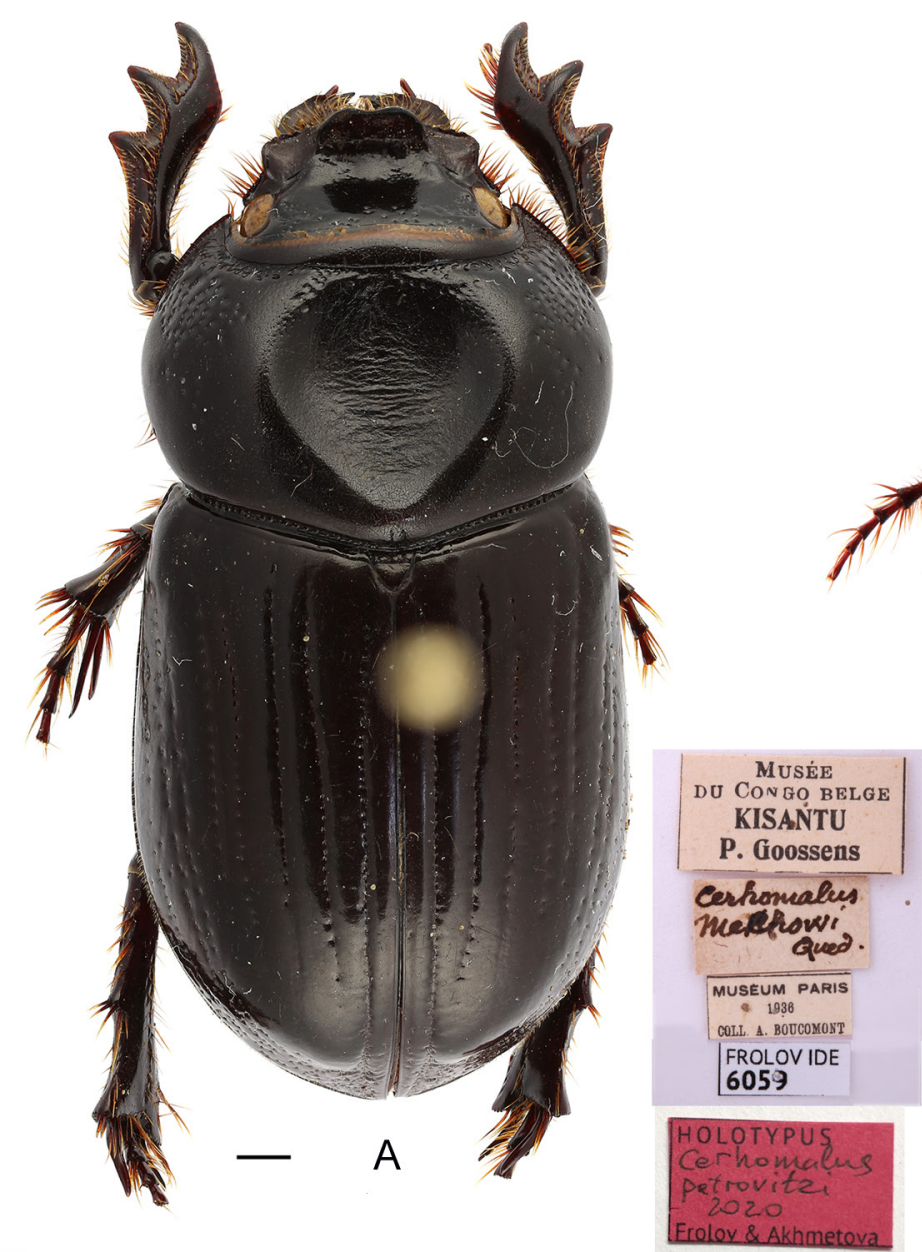

B
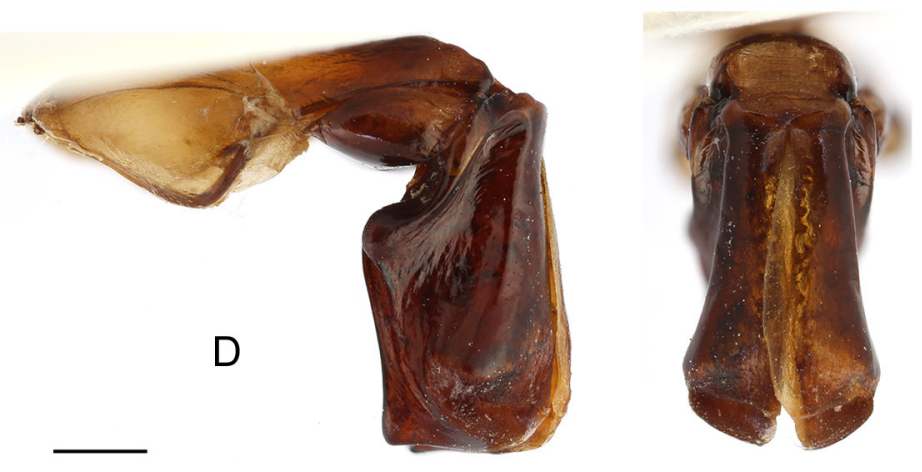

$\mathrm{E}$
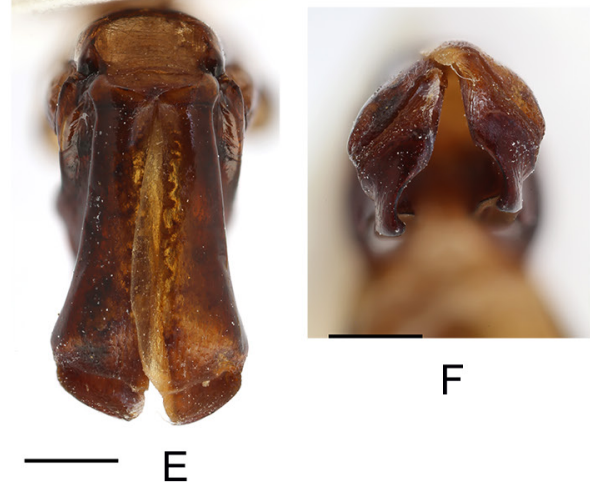
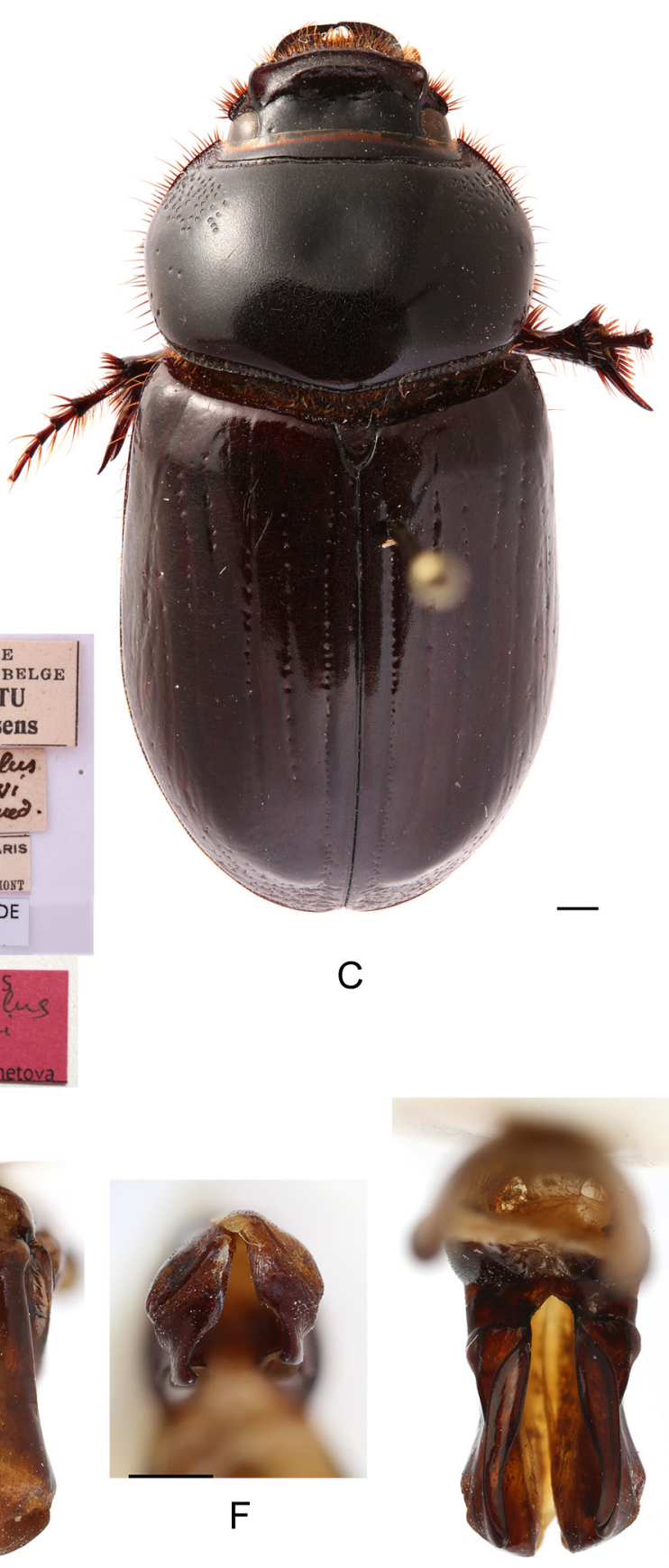

$-G$

Fig. 3. Cerhomalus petrovitzi sp. nov. A-B, D-G. Holotype, ô (MNHN). C. Paratype, $q$ (RMCA). A, C. Habitus in dorsal view. B. Labels. D. Aedeagus in lateral view. E. Parameres in dorsal view. F. Parameres in apical view. G. Parameres in ventral view. Scale bars $=1.0 \mathrm{~mm}$. 


\section{Cerhomalus quedenfeldti sp. nov. \\ urn:lsid:zoobank.org:act:AC2F5EC0-10F3-4262-A85E-F06B7B699139}

Figs 4, 5D, 6

\section{Differential diagnosis}

Cerhomalus quedenfeldti sp. nov. is similar to C. mechowi and C. petrovitzi sp. nov. in having the apices of the parameres with semi-circular excavations in apical view and with more or less developed fossae on ventral sides bordered with a keel, but can be separated from them in having the ventral fossae on the apices of the parameres not bordered proximally (Fig. 4G-K, arrowed) and the apices of the parameres in lateral view acute-angled (Fig. 4D, H).

\section{Etymology}

The new species is named after Friedrich Otto Gustav Quedenfeldt (1817-1891), a German coleopterist.

\section{Type material}

\section{Holotype}

REPUBLIC OF THE CONGO • ○’; “Congo Brazzaville O.R.S.T.O.M. XI-1965 R. Paulian”; MNHN.

\section{Paratypes}

REPUBLIC OF THE CONGO • 1 đo ; "Mai 1978 Voka Congo Coll. Th. Porion"; MNHN; 6 q $о$; "Congo Brazzaville O.R.S.T.O.M. XI-1965 R. Paulian"; MNHN • 1 o; “CONGO BRAZZAVILLE XI-57 / ORSOM PARIS MOUCHET 1957”; MNHN • 1 \&; "Soil-Zoological Exp. Congo-Brazzaville Brazzaville ORSTOM / 18.10.1963 No 3 singled in park leg. Endrody-Younga"; HNHM • 1 ô; "SoilZoological Exp. Congo-Brazzaville Brazzaville ORSTOM park / 16.1.1964 No 695 soil trap in forest leg. Balogh \& Zicsi”; HNHM • 1 q; "Soil-Zoological Exp. Congo-Brazzaville Brazzaville ORSTOM

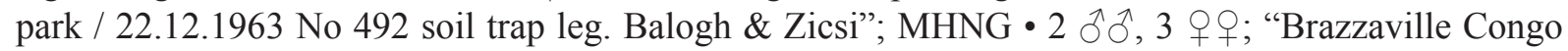
XI-1963 / MUSEUM PARIS Mission A. Descarpentiers et A. Villiers 1963-1964”; MNHN • 1 ô; "SoilZoological Exp. Congo-Brazzaville Kindamba, Kimboukou river/ 28.10.1963. No 38 singled on river side leg. Endrody-Younga"; MHNG.

\section{Description}

Male, holotype (Fig. 4A-B, D-G)

Body length $19.8 \mathrm{~mm}$. Colour uniformly brown to black.

Anterior margin of frontoclypeus somewhat rectangular, slightly convex in middle, bordered and slightly serrate in dorsal view (Fig. 4A). Frontoclypeus with a keel-shaped transverse process near anterior margin; height of keel about $2 / 3$ its width. Surface of frontoclypeus almost smooth, with minute punctures. Eye tubercles feebly developed. Eyes rather large: width about $1 / 6$ distance between eyes in dorsal view. Antennae 10-segmented.

Pronotum widely rounded laterally, as wide as elytra. Anterior border wide. Basal border narrow, keelshaped, separated from pronotal disc by deep groove with row of longitudinally elongated punctures. Pronotal disc depressed, somewhat rugose anteriorly. Most of pronotum surface covered with minute punctures separated by more than 3 puncture diameters. Anterolateral angles with much larger and denser punctures; posteriolateral angles with same punctures but in smaller numbers.

Scutellum subtriangular, narrowly rounded apically, about $1 / 10$ length of elytra.

Elytra 1.1 times longer than wide, with distinct humeral humps. Elytra widest in middle, lateral margins almost parallel in basal half. First (sutural) stria distinct, as groove with row of punctures. Other stria 


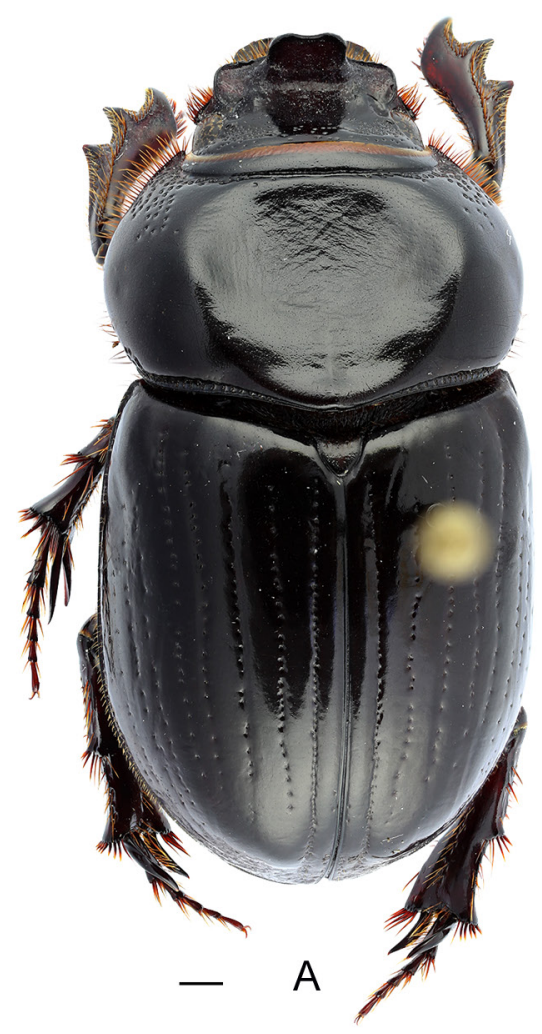

B
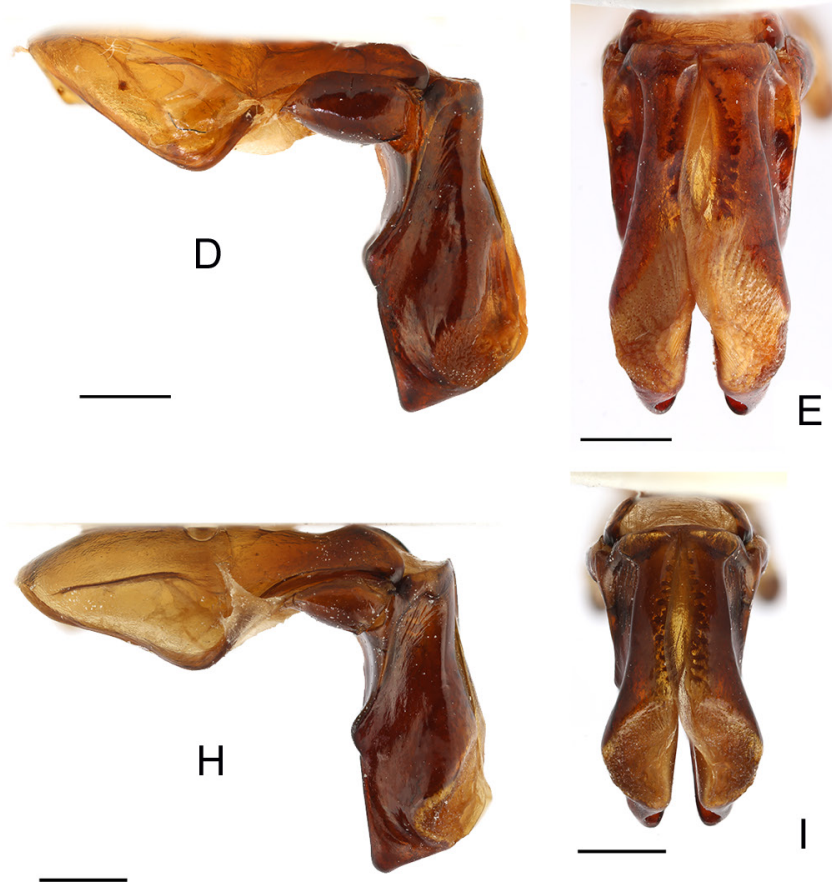
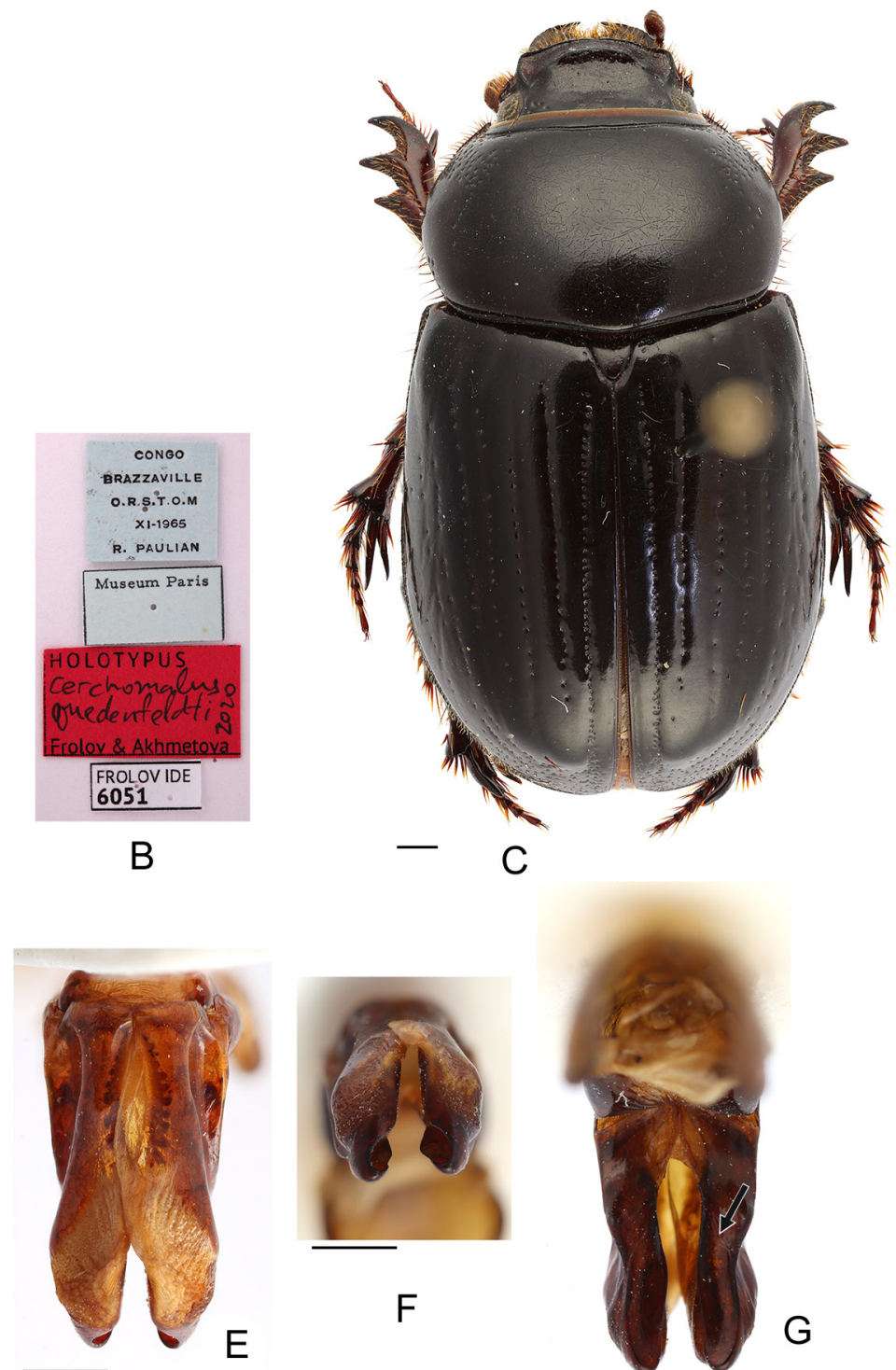

$\mathrm{F}$
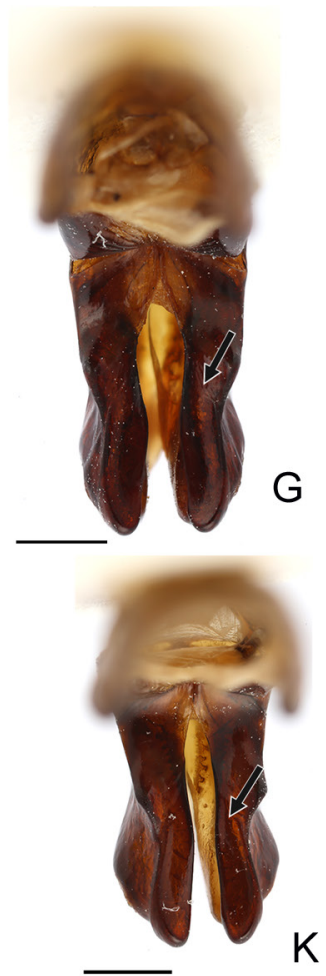

Fig. 4. Cerhomalus quedenfeldti sp. nov. A-B, D-G. Holotype, $ð$ (MNHN). C. Paratype, $\uparrow(\mathrm{MNHN})$. H-K. Paratype, $\widehat{\partial}$ from Voka $\odot$ (MNHN). A, C. Habitus in dorsal view. B. Labels. D, H. Aedeagus in lateral view. E, I. Parameres in dorsal view. F, J. Parameres in apical view. G, K. Parameres in ventral view. Scale bars $=1.0 \mathrm{~mm}$. 
before humeral humps as rows of round setiferous punctures. Striae laterad of stria 5 feebly distinct. Elytral intervals covered with minute punctures, somewhat sparser than those on pronotum.

Macropterous.

Abdominal sternite 8 medially longer than sternites 6 and 7 combined; sternite 6 about as long as sternite 7. Pygidium invisible from above, with slightly truncate apex. Plectrum triangular with rounded apex, wider than long.

Aedeagus. Apices of parameres acute angled in lateral view (Figs 4D, H, 5D), with semi-circular excavations in apical view (Fig. 4F, J) and with more or less developed fossae on ventral sides not bordered proximally (Fig. 4G, K).

\section{Female}

Female (Fig. 4C) differs from male in having a relatively smaller, convex pronotum without tubercles, frontoclypeus with much smaller, low keel not bimodal apically, protibial spur, and pygidium with rounded apex.

\section{Variation}

Body length of examined male paratypes varies from 18.5 to $22.5 \mathrm{~mm}$ (males) and from 16.0 to $19.0 \mathrm{~mm}$ (females).

\section{Distribution}

The species is known from a few localities in the Republic of the Congo (Fig. 6).
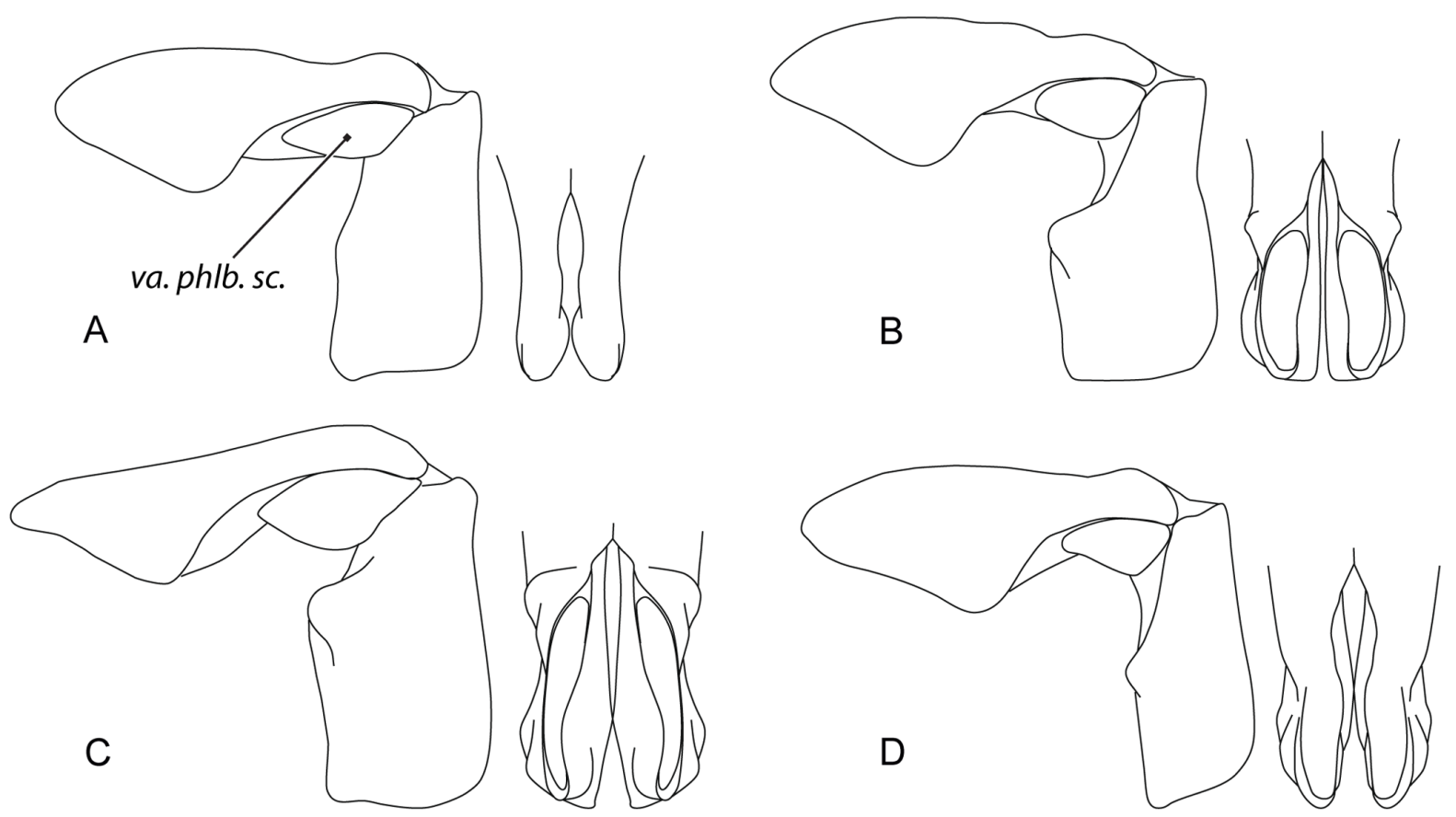

Fig. 5. Cerhomalus spp., scheme of aedeagus in lateral view and parameres in ventral view. A. C. absconditus (Petrovitz, 1971). B. C. mechowi Quedenfeldt, 1884. C. C. petrovitzi sp. nov. D. C. quedenfeldti sp. nov. Abbreviation: va. phlb. sc. = ventroapical phallobase sclerite. Not to scale. 


\section{Discussion}

Petrovitz (1971) argued that Cerhomalus should be considered a subgenus of Orphnus based on the presence of the similarly shaped head and pronotum in different species of Orphnus. Indeed, the shape of the head and pronotum varies considerably within Orphnus and some species of this genus show the habitus similar to that of Cerhomalus. However, these are mostly the secondary sexual characters that are found in males and are subject to reasonable allometric variation. Phylogenetic value of such characters is unclear. Also, Petrovitz (1971) did not recognize the unique structure of the ventroapical part of the phallobase (see above), the character that distinguishes Cerhomalus from Orphnus. Therefore, until a phylogenetic analysis supporting the changes of the generic status of Cerhomalus is available, we follow Quedenfeldt and the majority of other authors and consider Cerhomalus as a separate genus.

\section{Acknowledgements}

We thank all curators listed in the Materials and methods section for providing access to the specimens. An anonymous reviewer is thanked for the comments on the draft manuscript. The study was performed

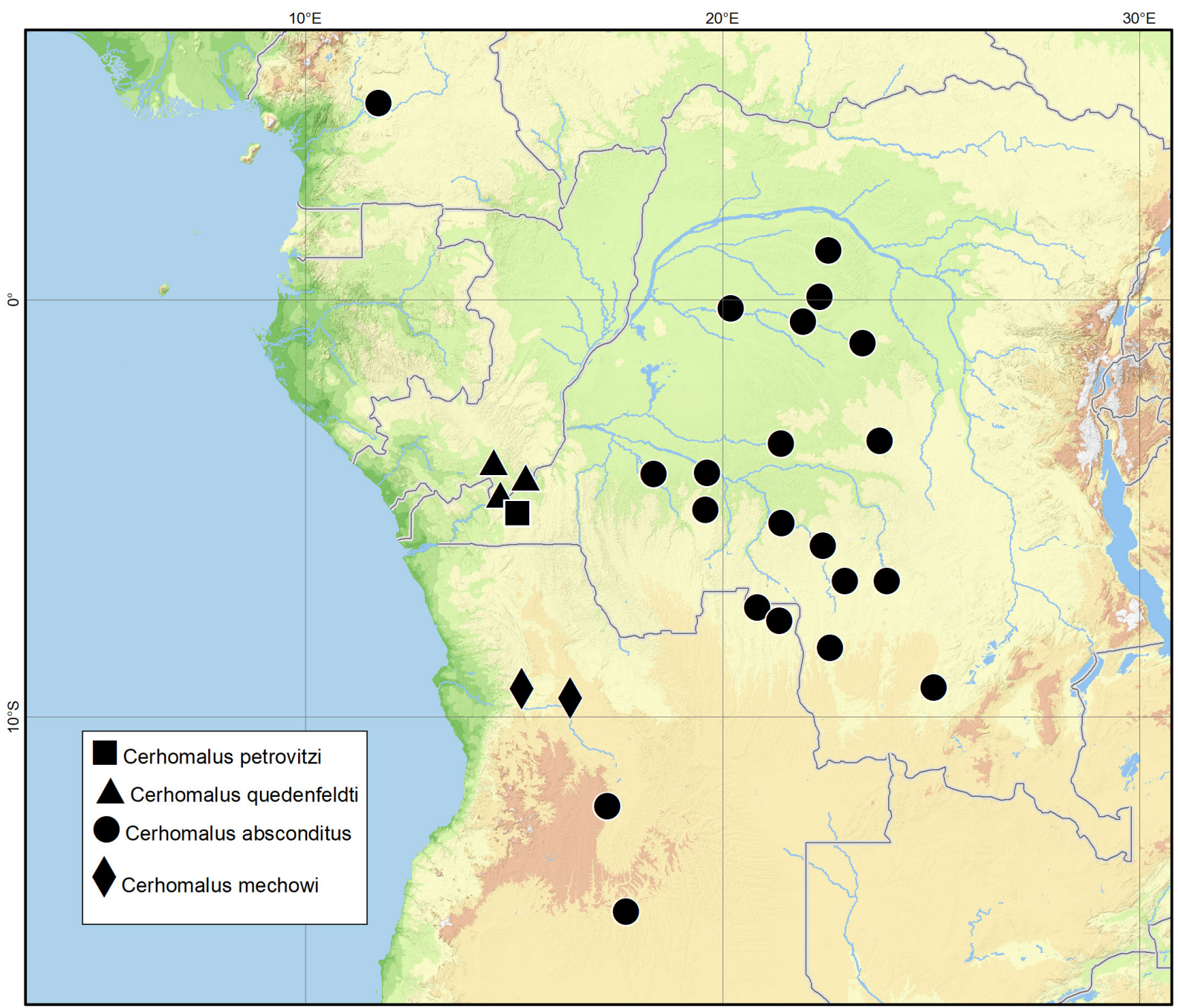

Fig. 6. Cerhomalus spp., distributional record map. 
in the framework of the Russian State research project AAAA-A19-119020690101-6 and partly supported by the Russian Foundation for Basic Research (grant 19-04-00565-A).

\section{References}

Arrow G.J. 1912. Pachypodinae, Pleocominae, Aclopinae, Glaphyrinae, Ochodaeinae, Orphninae, Idiostominae, Hybosorinae, Dynamopinae, Acanthocerinae, Troginae. In: Junk W. \& Schenkling S. (eds) Coleopterorum Catalogus 43: 1-66. W. Junk, Berlin.

Frolov A.V. 2005. Taxonomic position of Sissantobius mandibularis (Lansberge) and synonymy of Orphnus over Sissantobius (Coleoptera, Scarabaeidae, Orphninae). Journal of Afrotropical Zoology 2: $69-72$.

Frolov A.V. 2013. New and little known species of the genus Orphnus MacLeay (Coleoptera: Scarabaeidae: Orphninae) from the East African Rift. Zootaxa 3710: 297-300.

https://doi.org/10.11646/zootaxa.3710.3.8

Frolov A.V. \& Akhmetova L.A. 2016. Revision of the subgenus Orphnus (Phornus) (Coleoptera, Scarabaeidae, Orphninae). European Journal of Taxonomy 241: 1-20.

https://doi.org/10.5852/ejt.2016.241

Frolov A.V. \& Akhmetova L.A. 2020. Description of a new brachypterous scarab species, Orphnus brevialatus (Coleoptera: Scarabaeidae: Orphninae) from East Africa, with notes on flightlessness in the orphnines. Zootaxa 4750: 425-431. https://doi.org/10.11646/zootaxa.4750.3.8

Frolov A.V., Montreuil O. \& Akhmetova L.A. 2016. Review of the Madagascan Orphninae (Coleoptera: Scarabaeidae) with a revision of the genus Triodontus Westwood. Zootaxa 4207: 1-93.

https://doi.org/10.11646/zootaxa.4207.1.1

Frolov A.V., Akhmetova L.A. \& Vaz-de-Mello F.Z. 2017. Revision of the mainland species of the Neotropical genus Aegidium Westwood (Coleoptera: Scarabaeidae: Orphninae). Journal of Natural History 51: 1035-1090. https://doi.org/10.1080/00222933.2017.1319519

Karsch F. 1887. Altes und Neues über Koleopteren. Berliner Entomologische Zeitschrift 31: 1-8. https://doi.org/10.1002/mmnd.18870310105

Paulian R. 1948. Revision des Orphnus africains (Coleoptera, Scarabaeidae). Annales de la Société entomologique de France 117: 1-75.

Petrovitz R. 1971. Beitrag zur Kenntnis der Gattung Orphnus M’Leay (Orphninae, Scarabaeidae, Coleoptera). Revue de zoologie et de botanique africaines 84: 1-46.

Quedenfeldt G. 1884. Verzeichniss der von Herrn Major a. D. von Mechow in Angola und am QuangoStrom 1878-1881 gesammelten Pectinicornen und Lamellicornen. Berliner Entomologische Zeitschrift 28: 265-340. https://doi.org/10.1002/mmnd.18840280207

Quedenfeldt G. 1888. Beiträge zur Kenntniss der Koleopteren-Fauna von Central-Afrika nach den Ergebnissen der Lieutenant Wissman'schen Kassai-Expedition 1883 bis 1886. Berliner Entomologische Zeitschrift 32: 155-219.

Schmidt A. 1913. Coleoptera. Lamellicornia. Fam. Scarabaeidae. Subfam. Aegialinae, Chironinae, Dynamopinae, Hybosorinae, Idiostominae, Ochodaeinae, Orphninae. Genera Insectorum 150: 1-87. V. Verteneuil \& L. Desmet, Brussels.

Manuscript received: 5 October 2020

Manuscript accepted: 22 December 2020

Published on: 12 March 2021 
Topic editor: Nesrine Akkari

Topic editor: Max Barclay

Desk editor: Pepe Fernández

Printed versions of all papers are also deposited in the libraries of the institutes that are members of the EJT consortium: Muséum national d'histoire naturelle, Paris, France; Meise Botanic Garden, Belgium; Royal Museum for Central Africa, Tervuren, Belgium; Royal Belgian Institute of Natural Sciences, Brussels, Belgium; Natural History Museum of Denmark, Copenhagen, Denmark; Naturalis Biodiversity Center, Leiden, the Netherlands; Museo Nacional de Ciencias Naturales-CSIC, Madrid, Spain; Real Jardín Botánico de Madrid CSIC, Spain; Zoological Research Museum Alexander Koenig, Bonn, Germany; National Museum, Prague, Czech Republic. 